Jurnal Intelektualita: Keislaman, Sosial, dan Sains

Vol. 10 No. 2 (2021)

DOI: https://doi.org/10.19109/intelektualita.v10i2.9886

Copyright (C) 2021 Ahmad Rifa'i, Mitro Subroto

\title{
Pemenuhan Hak Pelayanan Kesehatan Umum Bagi Narapidana Perempuan
}

\author{
Ahmad Rifa'i ${ }^{1 *}$, Mitro Subroto ${ }^{1}$ \\ ${ }^{1}$ Politeknik Ilmu Pemasyarakatan, Indonesia
}

\begin{abstract}
Abstrak: Penelitian ini bertujuan untuk mengetahui pelaksanaan hak pelayanan kesehatan umum bagi narapidana perempuan di Lembaga Pemasyarakatan Tulungagung. Metode penelitian ini adalah kualitatif dengan analisis kualitatif deskriptif. Penelitian ini menemukan bahwa kurangnya kepatuhan terhadap pelayanan kesehatan bagi narapidana wanita yang disebabkan oleh beberapa faktor di antaranya kurangnya ketersediaan tenaga kesehatan secara utuh seperti dokter tetap, psikolog, terapis dan tenaga medis. Untuk itu, Pemerintah belum mengoptimalkan kinerjanya dalam bentuk pemenuhan hak narapidana. Selain itu, perlu adanya kerjasama yang baik antara Pemerintah dan petugas pemasyarakatan supaya hak narapidana dapat terpenuhi dengan dengan baik.
\end{abstract}

Kata Kunci: Narapidana, Pelayanan Kesehatan, Hak Narapidana

\begin{abstract}
This study aims to determine the implementation of the right to public health services for female prisoners at the Tulungagung Penitentiary. This research method is qualitative with descriptive qualitative analysis. This study found that the lack of compliance with health services for female prisoners was caused by several factors including the lack of full availability of health workers such as permanent doctors, psychologists, therapists and medical personnel. For this reason, the Government has not optimized its performance in the form of fulfilling the rights of prisoners. In addition, there needs to be good cooperation between the Government and correctional officers so that the rights of prisoners can be fulfilled properly.
\end{abstract}

Keywords: Prisoners, Health Services, Prisoners' Rights

\section{Pendahuluan}

Narapidana adalah terpidana yang sedang menjalani hukuman kehilangan kemerdekaan di Lembaga Pemasyarakatan. Lembaga Pemasyarakatan dan rumah tahanan negara, misalnya, yang diatur dalam Pasal 1 ayat (1) UU Pemasyarakatan, adalah tempat pelaksanaan hukuman dan pelatihan narapidana (Aris Kurniawan:2021). Kondisi lembaga pemasyarakatan harus ditinjau kembali untuk menghormati hak-hak narapidananya, berupa sarana dan prasarana yang memadai, merupakan tugas utama pemerintah untuk menghormati hakhak dasar narapidana. Dalam proses pembinaan lembaga pemasyarakatan berdasarkan sistem penjara, yang berasskan pancasila memberikan dampak jera bagi narapidana, agar mereka menyadari kesalahannya dan tidak mengulangi kejahatan yang telah dilakukannya. Selanjutnya proses pembinaan ini memungkinkan narapidana untuk masuk ke dalam masyarakat atau tempat asalnya dan dapat berperan aktif dalam kegiatan sosial yang sifatnya membawa negara Indonesia

\footnotetext{
* Corresponding Author: Ahmad Rifa'i (ahmadrifai1514@gmail.com). Politeknik Ilmu Pemasyarakatan, Indonesia
} 
menuju negara yang lebih maju dan berkembang. Dalam pasal 14 ayat (1) huruf D UU No. 12 Tahun 1995 tentang Lembaga Pemasyarakatan (UU Pemasyarakatan) menetapkan bahwa salah satu hak narapidana adalah mendapatkan pelayanan kesehatan Demi memelihara serta meningkatkan kualitas kesehatan dalam mencegah penyakit dibutuhkan suatu metode organisasi yang dilakukan secara bersama-sama sesuai yang termuat dalam pelayanan kesehatan masyarakat.

Banyak sekali beberapa aspek yang menyebabkan pembinaan narapidana tidak berjalan dengan maksimal, seperti contoh hak-hak narapidana yang belum diberikan sesuai dengan haknya sebagai warga negara. Dalam hal ini bisa jadi disebabkan oleh petugas lapasnya sendiri dengan narapidana karena kurangnya pemahaman tentang hak-hak narapidana yang disahkan oleh undang-undang, terkhusus bagi narapidana wanita. Tentu saja, hak-hak narapidana perempuan tidak selaras dengan narapidana laki-laki, dikarenakan narapidana wanita memiliki keistimewaan yang khusus yang tidak dialami oleh laki-laki seperti menstruasi, hamil, melahirkan dan menyusui (Ulfa: 2021). Kebutuhan khusus perempuan ini meliputi pemulihan kesehatan reproduksi, family planning, pelayanan kehamilan, dan amp; melahirkan serta perawatan setelah menderita kekerasan atau pelecehan intim (Putri Amalia, dkk: 2014).

Pemenuhan hak-hak narapidana wanita ini dalam kaitannya dengan isu-isu tersebut harus dihormati. Terkadang pemerintah dan opini publik menutup mata terhadap fenomena ini, jika Anda seorang wanita, apalagi jika Anda dikurung di penjara, Anda tentu memiliki kebutuhan yang tidak sesuai dengan kebutuhan pria. Perbandingan tersebut (narapidana pria dan wanita) mensyaratkan terdapat perlakuan yang tidak seimbang antara keduanya. Pelayanan kesehatan di Lapas merupakan bagian integral dari kesehatan warga.
Dengan begitu kesehatan masyarakat akan berdampak positif dengan dilakukannya pelayanan kesehatan yang optimal di dalam Lembaga Pemasyarakatan. Tetapi dalam kenyataannya Lapas terkadang gagal mencukupi kebutuhan dan kesehatan narapidana permpuan seperti yang diusulkan secara internasional bagi prinsip-prinsip hak asasi manusia dan keadilan sosial (Firmansyah, dkk:2019).

Kebijaksanaan dan pengaplikasian pengelolaan Lapas mengenai kesehatan narapidana wanita masih sangat berbeda di semua lembaga pemasyarakatan di Indonesia. Sayangnya, kondisi penjara seringkali tidak mencerminkan keragaman ini, dan akibatnya hak perempuan atas pemenuhan kebutuhan khusus tidak terlindungi. Apalagi bagi narapidana yang bergaul dengan narapidana pria, misalnya dalam perkara narkoba. Walaupun pada umumnya narapidana perempuan hanya mencakup sebagian kecil dari total populasi di Lapas, namun keberadaan narapidana perempuan tidak boleh diremehkan \& harus dihargai. Dari informasi yang dipublikasikan Direktorat Jenderal Pemasyarakatan tentang citra global narapidana perempuan di seluruh Lapas di Indonesia, yaitu sebagai berikut:

Tabel 1. Jumlah Narapidana Wanita

\begin{tabular}{|c|c|}
\hline Tahun & Narapidana Wanita \\
\hline 2018 & 9042 \\
\hline 2019 & 9325 \\
\hline Jun 2020 & 8397 \\
\hline
\end{tabular}

Banyak penjara di Indonesia yang menempati gedung-gedung tua dengan ruang terbatas dan infrastruktur yang tidak memadai . Masalah tersebut juga diperparah terhadap kondisi lapas yang banyak (overcrowded) \& di antaranya memiliki kelebihan kapasitas (Andansari:2014). Di Indonesia, hanya ada 33 penjara yang dirancang khusus untuk menampung perempuan. Lebih dari separuh narapidana ditempatkan di fasilitas yang dirancang khusus untuk wanita, sementara separuh 
lainnya ditempatkan di penjara universal (bercampur dengan narapidana pria, bahkan jika mereka berada di blok yang terpisah). Maka dengan hal itu, Pemerintah melalui Kementerian Hukum dan Hak Asasi Manusia telah berupaya untuk menambah jumlah lembaga pemasyarakatan wanita. Menteri Hukum dan Hak Asasi Manusia, Yasonna H Laoly, berkomentar jika anggaran cukup, dimungkinkan untuk membangun penjara wanita secara bertahap. Lapas perempuan masih sangat langka karena di beberapa daerah masih bercampur, memang idealnya dipisahkan antara laki-laki, perempuan dan anak-anak (Penny Naluria, 2020).

\section{Metode Penelitian}

Dalam penelitian ini, pendekatan kualitatif diterapkan yang menekankan pada pengamatan terhadap realitas dan mengkaji substansi makna dari realitas tersebut. Analisis dan pemahaman penelitian kualitatif sangat dipengaruhi oleh kekuatan kata dan frasa yang digunakan. Oleh karena itu, penekanan penelitian kualitatif adalah pada proses dan makna hasil. Fokus penelitian kualitatif lebih menitikberatkan pada elemen manusia, objek dan institusi, serta pada interaksi atau keterkaitan antara elemen-elemen tersebut, dalam upaya suatu peristiwa, sikap atau kenyataan. Pengumpulan informasi dilakukan melalui penelusuran literatur menggunakan kumpulan kajian regulasi dan regulasi terkait dengan subjek penelitian di lembaga pemasyarakatan Kelas IIB Tulungagung. Mengingat jumlah narapidana perempuan lebih sedikit dibandingkan narapidana laki-laki, hal ini seringkali membuat kebutuhan permpuan kurang terpenuhi. Setelah mendapatkan data yang diurutkan secara sistematis dan komprehensif, dilakukan analisis kualitatif.

\section{Hasil dan Pembahasan}

\section{Gambaran Kondisi Unit Pelaksana Teknis Pemasyarakatan}

Dalam kurun waktu 2016 hingga 1 Agustus 2020, suasana Lapas dan Rutan di Indonesia tergolong ekstrim overcapacity (tingkat kepegawaian di atas 150\%) yang digambarkan dengan tingkat ketenagakerjaan (jumlah narapidana dan narapidana dengan pejabat negara). Data yang diperoleh berdasarkan 33 Kanwil Kementerian Hukum dan HAM mengenai kondisi Lapas/Rutan di Indonesia, maka masih ada 7 Kanwil yang tidak di atas kapasitasnya. Oleh karena itu, 76\% kantor wilayah di 26 provinsi di Indonesia terus mengalami kelebihan kapasitas (Latifah, 2019).

Per Agustus 2020, data diperoleh berdasarkan 523 Lapas dan Rutan dengan kapasitas 133.086 orang, saat ini dihuni 226.068 orang, yang berarti menampung lebih dari 92.982 orang atau 70\%. Penghuni setiap UPT Lembaga Pemasyarakatan tidak merata, ada yang kelebihan kapasitasnya mencapai di atas $100 \%$, hingga di atas 400\%. Dari angka ini kita lihat persamaannya akan bertambah, hal ini karena penerapan aturan di Indonesia selalu berakhir dengan penahanan dalam bentuk penjara dan ini sulit untuk dilarang karena undang-undang yang mengaturnya. Kondisi ini menyebabkan perempuan di Lapas/Rutan kurang mendapat perhatian dan tidak mendapatkan perlakuan yang layak (Aris Kurniawan, 2021).

Per 16 November 2020, jumlah perempuan yang ditahan dan ditahan di seluruh Lapas dan Rutan di Indonesia sekitar 12.454 orang, dengan keadaan ini dapat dilihat berapa jumlah narapidana/tahanan perempuan yang harus dipertimbangkan. Oleh karena itu, berdasarkan situasi tersebut, perlu diperhatikan hak atas kesehatan yang harus diberikan kepada narapidana 
yang ada di seluruh unit pelaksana teknis pemasyarakatan.

\section{Indikator Hak Atas Kesehatan}

Hak kesehatan yang harus diberikan kepada narapidana di Lembaga Pemasyarakatan harus mengandung unsur yang krusial. Menurut Trio Sandra dan Malik Akbar (2021), unsur krusial yang perlu dipenuhi di Lembaga Pemasyarakatan yakni:

1. Ketersediaan. Meliputi infrastruktur kesehatan, peralatannya dan factor kesehatan yang krusial seperti air bersih, sanitasi, klinik maupun factor lain yang berkaitan dengan medis. Dan juga yang tidak kalah pentingnya yaitu tnaga medis yang terlatih dan berpngalaman, dikarenakan tanpa sumber daya manusia yang baik, infrastruktur kesehatan tidak dapat digunakan secara optimal.

2. Aksesibilitas. Dalam mengakses Puskesmas, Puskesmas wajib gampang dijangkau oleh siapa saja serta tidak boleh didiskriminasi. Aksesibilitas wajib mempunyai 4 dimensi yang silih terpaut:

a. Ketanpaprasangkaan; Pelayanan berbasis sarana, benda serta pelayanan kesehatan wajib gampang diperoleh serta diperoleh tanpa mengecualikan siapapun juga.

b. Akses raga; Dalam pelayanannya, seluruh sarana wajib bisa diakses secara fisik serta berguna untuk seluruh orang, paling utama kelompok rentan semacam wanita.

c. Akses ekonomi; Dalam pelayanannya, seluruh sarana wajib terjangkau oleh seluruh golongan.

d. Data masuk; Tiap orang berhak buat mencari serta mendapatkan data tanpa hambatan.

3. Penerimaan. Seluruh sistem tenaga sanitasi, baik benda ataupun jasa, wajib diterima oleh etika kedokteran serta selaras dengan budaya.

4. Mutu. Pelayanan kesehatan wajib bermutu baik, tercantum tenaga kedokteran yang handal ataupun profesional, obat- obatan serta perlengkapan yang terstandarisasi serta tidak kadaluarsa, air minum yang sehat serta sanitasi yang baik.

\section{Wujud Pelayanan Kesehatan di Lapas/Rutan}

Sebagian wujud pelayanan kesehatan di Lapas/ Rutan seperti berikut:

1. Pelayanan publik. Narapidana memperoleh pelayanan kesehatan yang metode kesehatannya sudah didetetapkan oleh Lapas/ Rutan. Di dalamnya masih ada bermacam perihal, ialah: tempat kerja, zona servis, perlengkapan, obat- obatan, ruang servis.

2. Fasilitas/ prasarana pelayanan tertentu. Lapas/ Rutan harus membagikan pelayanan spesial yang membutuhkan penindakan spesial serta handal untuk narapidana yang mengidap penyakit berat, semacam TBC, HIV serta ibu yang mengandung ataupun melahirkan. Oleh sebab itu, Lapas butuh merekrut tenaga kedokteran yang diperoleh dengan bekerja sama dengan dinas kesehatan terdekat.

\section{Keadaan dalam Pemenuhan Hak Pelayanan Kesehatan Narapidana Wanita di Lapas Kelas IIB Tulungagung}

Sebagian suasana penegakan hak atas pelayanan kesehatan narapidana di Lapas IIB Tulungagung:

1. Narapidana wanita yang hamil mengakses pelayanan kesehatan secara langsung. Mengingat Lapas Tulungagung cuma mempunyai tenaga kedokteran yang terbatas, maka bila terjalin kondisi darurat, warga binaan yang hamil wajib dirujuk ke rumah sakit terdekat.

2. Kesenjangan antara pelayanan kesehatan dengan kebutuhan warga binaan yang hamil. Kesenjangan ini diakibatkan tidak terdapatnya ketentuan spesial untuk warga binaan yang hamil, sebab ketentuan yang diberikan cuma 
buat warga binaan pada biasanya, oleh sebab itu lembaga pemasyarakatan Tulungagung mempunyai keterbatasan obat- obatan di poliklinik. Umumnya, bagi poliklinik di dalam Lapas, ibu hamil dengan WBP cuma diberikan vit penambah darah.

3. Mutu fasilitas serta prasarana pelayanan kesehatan masih belum mencukupi. Keterbatasan ini pastinya sangat mempengaruhi terhadap mutu pelayanan kesehatan yang diberikan oleh poliklinik di Lapas Tulungagung. Keterbatasan ini diakibatkan sedikitnya standar kesehatan di poliklinik, sehingga infrastruktur kesimpulannya tidak mencukupi, misalnya terbatasnya persediaan obat-obatan serta tidak terdapatnya bidan yang bisa menanggulangi WBP warga binaan yang hamil, cuma terdapat perawat.

\section{Hambatan Mengenai Pemenuhan Pelayanan Kesehatan Untuk Narapidana Wanita}

Dalam rangka pembinaan WBP wanita, Lembaga Pemasyarakatan harus memenuhi hakhaknya salah satunya yaitu hak mendapatkan pelayanan kesehatan. Secara universal diketahui bahwa ada 2 hak dasar, yaitu hak sosial \& hak pribadi. Dari adanya hak-hak sosial tersebut timbul suatu hak yang sangat penting, yaitu hak atas pelayanan kesehatan (right to health care) yang kemudian melahirkan hak-hak kodrat manusia lainnya seperti pelayanan kesehatan (right to health care); perawatan medis \& layanan medis. Hak untuk mendapatkan perawatan spiritual bagi narapidana terkait dengan pemenuhan kebutuhan psiko-moral dan kepribadian. Kegiatan keagamaan baik dalam peribadahan ataupun kegiatan keagamaan yang lainnya harus dioptimalkan demi memaksimalkan tujuan pembinaan (I Putu, 2021).

$\begin{array}{rrr}\begin{array}{c}\text { Lembaga } \\ \text { penyelenggara }\end{array} & \begin{array}{c}\text { Pemasyarakatan } \\ \text { program pembinaan }\end{array} & \text { sebagai } \\ \text { harus }\end{array}$

memenuhi hak-hak narapidana-nya dengan semaksimal mungkin, walaupun dalam pelaksanaannya masih terdapat kekurangan. Salah satunya yaitu hak mendapatkan pelayanan kesehatan, dalam hal ini masih ditemukan beberapa kendala dalam memberikan hak tersebut. Serta juga terdapat kendala dalam pelayanan konseling psikologis karena tidak adanya psikolog di dalam Lembaga Pemasyarakatan. Hambatan inilah yang dapat mempengaruhi warga binaan itu sendiri apalagi terhadap narapidana wanita yang seringkali psikis dan fisiknya bermasalah.

\section{Strategi Penerapan Pemenuhan Pelayanan Kesehatan Untuk Narapidana Perempuan}

Perlu adanya strategi dalam mengatasi kekurangan infrastruktur di Lapas, dengan hal ini harus diatasi dengan cara bekerjasama dengan pihak lain untuk mengatasi hal tersebut. Dengan berupaya melakukan koordinasi secara intens dengan para pemimpin untuk menghasilkan solusi dalam permasalah ini. Berikut beberapa strategi dalam mengatasi hal tersebut (Olivia:2017):

1. Menyalurkan bimbingan kerohanian kepada warga binaan berbentuk ceramah, dan pembelajaran agama. Sedangkan pemeliharaan jasmani dilakukan melalui penyelenggaraan kegiatan olahraga baik perorangan, permainan dan sejenisnya yang bertujuan guna melindungi dan meningkatkan kesehatan jiwa dan kebugaran jasmani.

2. Membangun jalinan kerjasama terhadap Instansi lain khususnya Dinas Kesehatan. Dengan menjalin hubungan kerjasama dengan instansi lain tentusaja bisa memecahkan kasus permasalahan kesehatan di dalam Lapas. Kolaborasi ini dapat dilaksanakan baik tingkat kabupaten/kota hingga tingkat provinsi. Upaya ini ditujukan demi menyelamatkan interpretasi narapidana guna untuk membangun kepribadian yang lebih baik dari sebelumnya. 
3. Menghubungkan keluarga narapidana. Demi memberikan dukungan dan semangat kepada narapidana, maka pihak keluarga narapidana harus memberikan motivasi dan semangatnya kepada narapidana agar ia tidak merasa dikucilkan dan menyesali perbuatannya. Dengan menghubungkan keluarga warga binaan, diharapkan keluarga WBP lebih sadar, sehingga keluarga WBP dapat memahami bahwa narapidana adalah orang yang hilang kemerdekaannya, yang tidak boleh diabaikan dan membutuhkan sesuatu atau motivasi untuk menjalani hidup.

4. Melakukan penjelasan atau sosialisasi kepada masyarakat bahwa mantan narapidana itu juga manusia yang terkadang berbuat salah. Kita meyakinkan kepada masyarakat bahwa ia (mantan narapidana) telah mendapatkan pembinaan baik dari rohani nya maupun jasmani serta juga telah mendapatkan ketrampilan yang bisa ia terapkan ketika telah selesai menjalani masa hukumannya atau telah bebas. Sebagai petugas Lapas kita bukan hanya menjadi pegawai negeri saja melainkan juga pembina dan pelayan terhadap narapidana. Sukses tidaknya pembinaan tergantung dari tiga factor ini, ialah petugas pemasyarakatan, masyarakat, dan warga binaan pemasyarakatan itu sendiri.

\section{Kesimpulan}

Berdasarkan penjelasan ulasan tentang pemenuhan pelayanan kesehatan bagi narapidana, maka dapat ditarik kesimpulan sebagai berikut: 1) Pemenuhan pelayanan kesehatan bagi narapidana khususnya narapidana wanita belum berjalan dengan baik secara universal. Dalam hal ini disebabkan karena tenaga medis yang kurang yaitu seperti dokter umum, psikolog \& terapis. Serta peralatan medis yang terbatas danjuga obat-obatan yang terbatas di dalam Lembaga Pemasyarakatan.
Meskipun demikian, pelayanan kesehatan telah diupayakan semaksimal mungkin demi kesehatan warga binaan. 2) Hambatan yang dihadapi Lembaga Pemasyarakatan adalah (a) pengobatan tenaga kesehatan bagi narapidana yang masih sakit belum teruji karena keterbatasan anggran; (b) peralatan kesehatan \& obat-obatan relatif tidak mencukupi untuk menunjang kesehatan narapidana; (c) jumlah tenaga kesehatan penanggung jawab masih kurang, dan yang terpenting adalah dokter umum, sebagai akibat dari distribusi pelayanan kesehatan yang belum optimal; (d) tidak adanya tenaga medis yang terampil, misalnya psikolog. 3) Pelaksanaan hak narapidana atas pelayanan kesehatan di lembaga pemasyarakatan/rutan belum efektif, ternyata karena sarana dan prasarana yang belum memadai serta anggaran yang sangat terbatas dan perlunya penegakan pelayanan kesehatan yang lebih besar dan tanggung jawab penanggulangannya berasal dari Kalapas \& Karutan itu sendiri.

\section{Daftar Pustaka}

Andansari, P. A. (2014). Pemenuhan Hak Memperoleh Pelayanan Kesehatan Bagi Narapidana Wanita yang Sedang Hamil (Studi pada Lembaga Pemasyarakatan Wanita Klas IIA Malang). Kumpulan Jurnal Mahasiswa Fakultas Hukum, 1(1).

Dagi, Ovilia.F. (2017). Pemenuhan Hak Pelayanan Kesehatan Terhadap Narapidana di Lembaga Pemasyarakatan Kelas IIA Sungguminasa Kabupaten Gowa.

Firmansyah, R., A.Rani, F., \& Adwani, A. (2019). Pemenuhan Pelayanan Kesehatan \& Konsumsi Bagi Narapidana pada Lapas \& Rutan. Jurnal Magister Hukum Udayana (Udayana Master Law Journal), 8(3), 433.

Kurniawan, M. A. (2021). Pemenuhan Hak Pelayanan Kesehatan Terhadap Narapidana Wanita Hamil Di Lapas/Rutan. JUSTITIA: Jurnal Ilmu Hukum \& Humaniora, 8(2), 313318.

Latifah, M. (2019). Overcrowded Pada Rumah Tahanan dan Lembaga Pemasyarakatan Di 
Indonesia: Dampak dan Solusinya. INFO Singkat Bidang Hukum : Kajian Singkat Terhadap Isu Aktual dan Strategis. Vol. XI, No. 10/II/Puslit/Mei/2019.

Suwardana, I P. R. B. (2021). Pelaksanaan Pelayanan Kesehatan bagi Narapidana Hamil. JUSTITIA: Jurnal Ilmu Hukum dan Humaniora, Vol. 8 No.4 Tahun 2021.

Ulfa, D. T. (2021). Perlakuan Khusus Terhadap Kelompok Rentan : Kewajiban dan Hak Pelayanan Kesehatan Terhadap Warga Binaan Wanita Menyusui Di Rumah Tahanan Negara Kelas IIB Sambas. JUSTITIA: Jurnal Ilmu Hukum dan Humaniora, Vol. 8 No.4 Tahun 2021.

Utami, P. N. hamil(2020). Pemenuhan Pelayanan Kesehatan Bagi Narapidana Perempuan di Lembaga Pemasyarakatan Narkotika Langkat (Fulfillment of Health Services for Female Inmates at Langkat Narcotics Correctional Institution). Sumber, 2019, 8-397.

Wijaya, T. S., Malik A. M. R. (2021). Pemenuhan Hak Mendapatkan Pelayanan Kesehatan Bagi Narapidana (Studi di Lembaga Pemasyarakatan Kelas II A Curup). Jurnal Komunikasi Hukum, Volume 7, No. 1, Februarui 2021.

Peraturan Pemerintah Nomor 31 Tahun 1999 tentang Pembinaan dan Pembimbingan Warga Binaan Pemasyarakatan

Undang-Undang Nomor 12 Tahun 1995 tentang Pemasyarakatan 